\title{
Complement Induces a Transient Increase in Membrane Permeability in Unlysed Erythrocytes
}

\author{
Jose A. Halperin," Anne Nicholson-Weller," Carlo Brugnara," and Daniel C. Tosteson* \\ *Department of Physiology and Biophysics, Harvard Medical School, and ${ }^{\ddagger}$ Charles A. Dana Research Institute, Harvard-Thorndike \\ Laboratories, and the Department of Medicine, Beth Israel Hospital, Harvard Medical School, Boston, Massachusetts 02115
}

\begin{abstract}
The effects of low concentrations of human serum on antibody-sensitized sheep erythrocytes (EA) were studied. We report that exposure to low concentrations of serum induced a large but transient increase in the membrane permeability of those EA that do not lyse. This change in the permeability of the erythrocyte membrane resulted in net uptake of $\mathrm{Na}^{+}$and decrease in cell $\mathrm{K}^{+}$, without affecting the total internal cation content. Although exposure to serum also allowed for net uptake of larger molecules like L-glucose, it did not lead to cell swelling. Experiments with sera genetically deficient in one of the terminal complement components showed that $\mathrm{C} 8$, but not C9, was required to produce the observed change in membrane permeability. Therefore, we propose that the $\mathrm{C} 5 \mathrm{~b}-8$ complex can mediate the transient increase in permeability observed in unlysed erythrocytes during complement activation by whole serum.
\end{abstract}

\section{Introduction}

Activation at the cell surface of the complement system can lead to lysis of erythrocytes or nucleated cells (1). Nucleated cells are more resistant to complement-mediated cytolysis than mammalian erythrocytes (2), probably as a result of repair mechanisms triggered by complement attack (3-7). Although much is known about the mechanism by which the complement components produce the membrane damage that leads to the lysis of erythrocytes (reviewed 8, 9), less is known about the sublytic effects of complement on the mammalian erythrocyte. $\mathrm{C} 4$ and $\mathrm{C} 3$ antigen are bound to erythrocytes in situations in which complement is activated, such as in the presence of autoantibodies (10) and when erythrocytes are stored in plasma (11), but C5b-9 antigen has not been detected in unlysed cells (10). These findings are explained because complement mediated lysis, especially by homologous complement, is inhibited by at least two membrane proteins: the decay accelerating factor $(\mathrm{DAF})^{1}(12)$ and the C8b binding

Address reprint requests to Dr. Halperin, Department of Physiology and Biophysics, Harvard Medical School, 25 Shattuck St., D2-155, Boston, MA 02115.

Received for publication 23 November 1987 and in revised form 17 March 1988.

1. Abbreviations used in this paper: $\mathrm{C} 8 \mathrm{bp}, \mathrm{C} 8 \mathrm{~b}$ binding protein; DAF, decay accelarating factor; EA, antibody-sensitized sheep erythrocytes; GVB, isotonic veronal-buffered saline, $\mathrm{pH} 7.4$, containing $0.1 \%$ gelatin; GVB.D ${ }^{2+}$, GVB containing $10 \mathrm{mM}$ dextrose, $0.15 \mathrm{mM} \mathrm{CaCl}_{2}$ and $0.5 \mathrm{mM} \mathrm{MgCl}$; GVB-EDTA, GVB containing 0.04 EDTA; TrisMOPS, Tris-4-morpholinopropanesulfonic acid.

J. Clin. Invest.

(c) The American Society for Clinical Investigation, Inc.

0021-9738/88/08/0594/07 \$2.00

Volume 82, August 1988, 594-600 protein (C8bp), also known as the homologous restriction factor $(13,14)$. DAF limits the cleavage of C3 and C5 and thereby limits the amount of C5b-8 $(12,15,16)$ generated by the membrane-bound C5 activating enzyme, whereas C8bp interferes with the interaction of $\mathrm{C} 8$ and/or $\mathrm{C} 9$ with $\mathrm{C} 5 \mathrm{~b}-7$ or $\mathrm{C} 5 \mathrm{~b}-8$ complex $(13,14)$.

To characterize further the nonlytic effects of complement on erythrocytes, sheep erythrocytes sensitized with antibody were exposed to diluted human serum and changes in membrane permeability, cation composition and cell volume were monitored in the unlysed erythrocytes. In these experiments complement induced a transient increase in membrane permeability to $\mathrm{Na}^{+}$and $\mathrm{K}^{+}$, as well as to L-glucose, which resulted in a change of the cation composition of the cells. This change in permeability did not result in measurable cell swelling or subsequent lysis. From experiments using sera genetically deficient in either $\mathrm{C} 8$ or $\mathrm{C} 9$ we concluded that activation of complement through the C8 step was required to produce sublytic permeability changes and we speculate that $\mathrm{C} 5 \mathrm{~b}-8$ might be responsible for the transient increase in permeability of the erythrocyte membrane observed in our experiments.

Erythrocytes, as "innocent bystanders" $(17,18)$, are not protected by DAF from the binding and membrane insertion of C5b-7 complexes generated in the fluid phase; nor are they protected from the subsequent binding of $\mathrm{C} 8$ to the membrane bound $\mathrm{C} 5 \mathrm{~b}-7$. It is possible that sublytic insertion of $\mathrm{C} 5 \mathrm{~b}-8$ complexes into cell membranes may modulate cellular functions through transient changes in the permeability of the membrane of the target cell.

\section{Methods}

Complement reagents and assays. An isotonic veronal buffer solution containing $140 \mathrm{mM} \mathrm{NaCl}, 0.15 \mathrm{mM} \mathrm{CaCl}_{2}, 0.5 \mathrm{mM} \mathrm{MgCl}_{2}, 10 \mathrm{mM}$ dextrose, $0.1 \%$ gelatin, and $5 \mathrm{mM}$ veronal sodium, $\mathrm{pH} 7.3\left(\right.$ GVB. ${ }^{2+}$ ) was used in all the hemolytic assays. Fresh sheep erythrocytes, determined to be of the high $\mathrm{K}^{+}$phenotype (19) by measuring the internal cation composition, were obtained weekly by bleeding a single sheep. The sheep blood was initially anticoagulated with Alsever's solution (116 mM dextrose, $27 \mathrm{mM}$ Na-citrate, $72 \mathrm{mM} \mathrm{NaCl}, 2 \mathrm{mM}$ citric acid, pH 7.2) and later stored at $4^{\circ} \mathrm{C}$ in a preservation solution containing $140 \mathrm{mM} \mathrm{KCl}, 10 \mathrm{mM} \mathrm{NaCl}, 2.5 \mathrm{mM} \mathrm{NaH}_{2} \mathrm{PO}_{4}, 10 \mathrm{mM}$ glucose and $10 \mathrm{mM}$ Tris-MOPS buffer, $\mathrm{pH} 7.4$ at $4^{\circ} \mathrm{C}$. For sensitization with antibody, the cells were washed three times with veronal-buffered solution containing $140 \mathrm{mM} \mathrm{NaCl}, 0.1 \%$ gelatin, $0.04 \mathrm{M}$ EDTA and $5 \mathrm{mM}$ veronal sodium, pH 7.3 (GVB-EDTA), suspended in a 1/200 dilution of rabbit anti-sheep stroma antiserum (Cordis Laboratories, Miami, FL) in GVB-EDTA $\left(5 \times 10^{8} \mathrm{cells} / \mathrm{ml}\right)$ and incubated at $4^{\circ} \mathrm{C}$ for $30 \mathrm{~min}$ and at $37^{\circ} \mathrm{C}$ for an additional $30 \mathrm{~min}$. Antibody sensitized erythrocytes were washed three times in GVB-EDTA and either washed into GVB.D $D^{2+}$ for use or stored in preservation solution at $4^{\circ} \mathrm{C}$ for later use within the same week.

A pool of normal human sera was made from five healthy donors. Serum from a patient genetically deficient in C8 $(20,21)$ was generously provided by Dr. Peter Rice (Boston University Medical Center, 
Boston, MA); heparinized plasma from a patient genetically deficient in C9 (22) was generously provided by Dr. Thomas Lint (Rush Medical College, Chicago). The $\mathrm{C} 9$ deficient plasma was used without attempting to reverse the heparin anticoagulation. Isolated human $\mathrm{C} 8$ and $\mathrm{C} 9$ were purchased from Cordis and Cytotech (San Diego, CA), respectively. The sera used as complement sources were aliquoted and stored at $-70^{\circ} \mathrm{C}$; new aliquots were used for each experiment. For hemolytic assays, varying quantities of serum were diluted into $0.5 \mathrm{ml} \mathrm{GVB.D^{2+ }}$ containing $3 \times 10^{8}$ cells $/ \mathrm{ml}$, incubated for varying times at $37^{\circ} \mathrm{C}$, and the reaction terminated by the addition of $2.0 \mathrm{ml}$ of isotonic $\mathrm{NaCl}$ solution and centrifugation. The hemoglobin in the supernatant was measured by the absorbancy at either 541 or $412 \mathrm{~nm}$.

Determination of intracellular cation content. Fresh erythrocytes were washed three times with a washing solution containing $150 \mathrm{mM}$

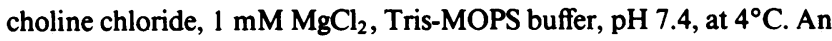
aliquot of cells was then suspended in an approximately equal volume of choline washing solution, and on this cell suspension hematocrit, $\mathrm{Na}^{+}$(1:50 dilution in 0.02\% Acationox; American Scientific Products, McGraw Park, IL), $\mathrm{K}^{+}$(1:500 dilution) and hemoglobin $\left(\mathrm{OD}_{541}\right)$ concentrations were determined. $\mathrm{Na}^{+}$and $\mathrm{K}^{+}$concentrations were measured by atomic absorption spectrometry (model 5000; Perkin-Elmer, Wellesley, MA). Cell $\mathrm{Na}^{+}$and $\mathrm{K}^{+}$concentrations were calculated from the measured concentrations of these ions and hemoglobin as well as the hematocrit of the cell suspension.

Measurement of ${ }^{22} \mathrm{Na}$ and $\left[{ }^{14} \mathrm{C}\right]-\mathrm{L}$-glucose uptake. Isotope $(2-3 \mu \mathrm{Ci}$ ${ }^{22} \mathrm{Na}$ [sp act $5 \mathrm{mCi} / \mathrm{mg}$; Amersham Corp., Arlington Heights, IL], or 3 $\mu \mathrm{Ci}\left[{ }^{14} \mathrm{C}\right]$-L-glucose [sp act $57 \mathrm{mCi} / \mathrm{mmol}$, Amersham] was added to $2.5 \mathrm{ml}$ of cell suspension in GVB.D ${ }^{2+}\left(3 \times 10^{8}\right.$ cells $\left./ \mathrm{ml}\right)$. The radioactivity in three $20-\mu l$ aliquots of each reaction mixture was measured to determine the initial specific activity of the isotopes. Serum was added to the prewarmed cell suspension at 0 time. At intervals thereafter, 0.4-ml samples were removed from the reaction mixtures and added to $0.5 \mathrm{ml}$ of isotonic choline chloride that had been layered on top of 0.4 $\mathrm{ml}$ of $n$-butylphthalate (Fisher Scientific Co., Fair Lawn, NJ) in $1.5 \mathrm{ml}$ Eppendorf centrifuge tubes (23). Each sample was centrifuged immediately for $20 \mathrm{~s}$ in an Eppendorf microcentrifuge (model 5412). The tubes were immersed in an ethanol-dry ice bath until the contents were frozen and then the tip of the tube containing the cell pellet was cut, placed into a 4-ml tube and the cells lysed with $1 \mathrm{ml}$ of $0.02 \%$ Acationox. The volume of extracellular fluid trapped by the cell pellet was less than $1 \%$ of the volume of cells in the pellet, as determined by sampling an equal volume of cell suspension containing $\mathrm{L}-\left[{ }^{14} \mathrm{C}\right]$ glucose in the absence of serum. The samples containing ${ }^{22} \mathrm{Na}$ were counted in a gamma counter (Auto-Gamma 500; Packard Instrument Co., Lynn, MA). The samples containing L- $\left[{ }^{14} \mathrm{C}\right]$ glucose were treated with trichloroacetic acid ( $10 \%$ final concentration) to precipitate the protein which was removed by centrifugation. An aliquot $(0.5 \mathrm{ml})$ of the supernatant was then suspended in scintillation fluid (Liquiscent; National Diagnostics, Somerville, NJ) and counted in a liquid scintillation spectrometer (Packard Tri-Carb).

The amount of $\mathrm{Na}^{+}$or L-glucose taken up by the cells at each time was calculated in millimoles per liter of cells as follows: $\mathrm{Na}^{+}$or L-glucose uptake $=\mathrm{cpm} /$ liter cells/specific activity, where $\mathrm{cpm} /$ liter cells $=\mathrm{cpm}$ counted in the lysate $\times 1 / \mathrm{vol} \times 100 /$ hematocrit; vol is the volume (in liters) of lysate counted and hematocrit is the fractional volume of cells (\%) in the lysate. The amount of cells present in the lysate was calculated using the hematocrit and concentration of hemoglobin of the initial cell suspension and the concentration of hemoglobin determined in each lysate. Specific activity was measured in counts per minute per millimole.

In order to assess whether this methodology can separate lysed ghosts from unlysed cells a control experiment was carried out at a serum dilution producing $100 \%$ lysis. Under these conditions no radioactivity over background was recovered in the pellet after centrifugation of the cell suspension. This indicates that erythrocyte ghosts do not sediment through the phthalate layer and, therefore, tracer trapped by the resealed ghosts does not contribute to the radioactivity measured in the unlysed cells.
Measurement of net $\mathrm{Na}^{+}$and $\mathrm{K}^{+}$fluxes and density distribution profiles. The net movements of $\mathrm{Na}^{+}$and $\mathrm{K}^{+}$at each time were determined simultaneously with the uptake of radioactive $\mathrm{Na}^{+}$. After counting, the $\mathrm{Na}^{+}$and $\mathrm{K}^{+}$content of the lysate was determined by atomic absorption spectrometry. The ion concentration in millimoles per liter of cells was calculated using the concentration of hemoglobin in the lysate and the hematocrit and concentration of hemoglobin of the initial cell suspension. Density distribution profiles were determined by the phthalate method as previously described (24).

\section{Results}

To investigate the effects of complement on those erythrocytes that survive exposure to low concentrations of serum, antibody-sensitized sheep erythrocytes (EA) were exposed to a concentration of human serum $(\approx 1 / 120)$ that produced $\approx 30 \%$ lysis upon incubation at $37^{\circ} \mathrm{C}$ in GBV.D ${ }^{2+}$. Since complement induces lysis by increasing the permeability of the cell membrane, it was of interest to assess whether changes in membrane permeability occurred in unlysed cells exposed to complement. Unlysed cells were separated from lysed cells by the phthalate procedure as described in Methods. The uptake of radiolabeled $\mathrm{Na}^{+}$and L-glucose by EA was measured at different intervals before and after the addition of serum. In the absence of serum, the influx of $\mathrm{Na}^{+}$and L-glucose were $\approx 2.6$ and $0.1 \mathrm{mmol} /$ liter cells $/ \mathrm{h}$, respectively. In the presence of a serum dilution that produced $\approx 30 \%$ lysis, the uptake of $\mathrm{Na}^{+}$and L-glucose by the unlysed cells increased 3-10-fold, as shown in Fig. 1, $a$ and $b$. The isotope uptake increased to reach

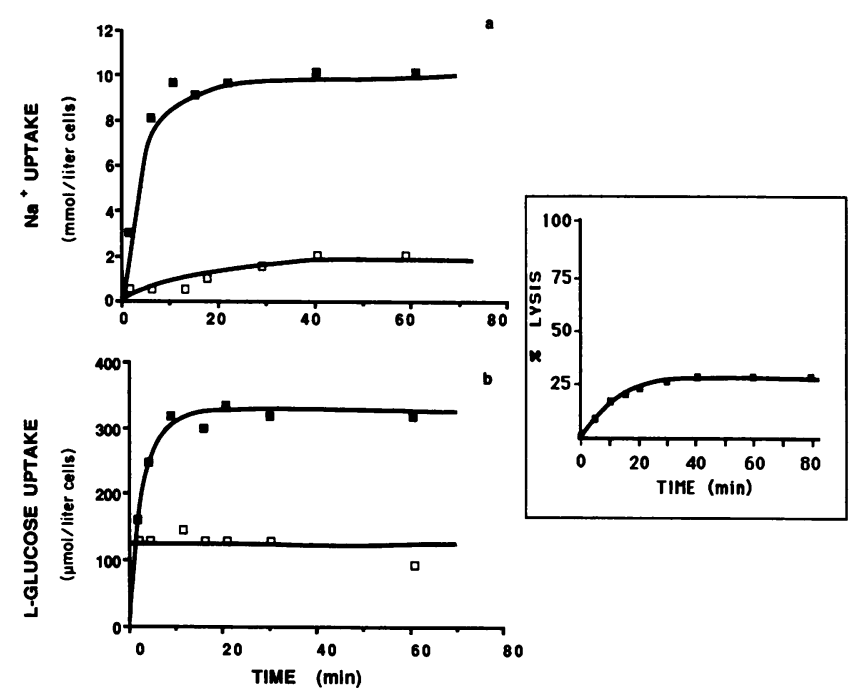

Figure $1 . \mathrm{Na}^{+}$and L-glucose uptake by sensitized erythrocytes (EA) in the presence and absence of human serum. $(a) \backsim, \mathrm{Na}^{+}$uptake in the presence of serum; $\square, \mathrm{Na}^{+}$uptake in the absence of serum. $(b)$. L-glucose uptake in the presence of serum, $\square$ L-glucose uptake in the absence of serum. EA $\left(2 \times 10^{8} / \mathrm{ml}\right)$ were exposed to a $1 / 120$ dilution of serum added simultaneously with the isotopes at $37^{\circ} \mathrm{C}$. At timed intervals an aliquot of the cell suspension was removed, the unlysed cells were recovered by centrifugation through phthalate, the amount of either ${ }^{22} \mathrm{Na}$ or $\mathrm{L}-\left[{ }^{14} \mathrm{C}\right]$ glucose in the cells measured and the uptake of $\mathrm{Na}^{+}$and $\mathrm{L}$-glucose calculated as described in Methods. (Inset) Survival of EA exposed to normal human serum. $0.5 \mathrm{ml}$ of a cell suspension containing $2 \times 10^{8}$ cells $/ \mathrm{ml}$ was incubated at $37^{\circ} \mathrm{C}$ with a $1 / 120$ dilution of serum. Samples were removed at timed intervals, diluted in $2 \mathrm{ml}$ saline solution and centrifuged to determine the lysis from the hemoglobin content of the supernatant (OD at $541 \mathrm{~nm}$ ). $100 \%$ lysis was determined by diluting a sample of the cell suspension in distilled water. 
maximal value following a time course parallel to that of the lysis (inset, Fig. 1). In the experiment depicted in Fig. $1 a$, the uptake of $\mathrm{Na}^{+}$reached a maximal and constant value when the cells were not at isotopic equilibrium with the extracellular medium (specific activity in the medium: $14 \times 10^{6} \mathrm{cpm} /$ mmol; specific activity in the cells: $4 \times 10^{6} \mathrm{cpm} / \mathrm{mmol}$ ). This suggested that the increase in the permeability of EA membranes induced by low serum concentrations was transient and was reversed before equilibration could be reached. Increasing concentrations of serum increased the total uptake of $\mathrm{Na}^{+}$by the unlysed cells as well as the number of cells lysed (Fig. 2, cf. the figure legend).

To evaluate further if complement induces a transient increase in membrane permeability in the unlysed cells, unidirectional influxes of $\mathrm{Na}^{+}$and L-glucose, were measured using radioactive tracers $\left({ }^{22} \mathrm{Na}\right.$ and $\left[{ }^{14} \mathrm{C}\right] \mathrm{L}$-glucose) at different times after the addition of serum to the cell suspension. Diluted serum was added to the cell suspension at 0 time and samples of the reaction mixture were subsequently removed at different time intervals, and mixed with the isotope to start the influx assay. Thereafter the samples were handled as described in Methods for the uptake assay. When the cell suspension was mixed with the isotope at 0 time, the uptake by EA in the presence and in the absence of serum was the same for the initial $2 \mathrm{~min}$. The first $2 \mathrm{~min}$ presumably represents the lag phase of complement activation. After $2 \mathrm{~min}$ a large increase in the uptake of both isotopes was observed in the serum treated cells (Figs. 3 and 4). The uptake increased until it reached a maximum value at $5 \mathrm{~min}$, and then progressively decreased to the original low value of the control cells. Since the linearity of tracer uptake required to calculate the initial unidirectional influx was not met within the time frame of the first three determinations $(30,60$, and $90 \mathrm{~s})$, the initial influx was estimated from the slope of the line connecting the origin with the value of the first measurement $(30 \mathrm{~s})$. From a plot of the rate constant $\left({ }^{\mathrm{i}} k_{0}\right)$ of the unidirectional influx $\left({ }^{\mathrm{i}} k_{0}\left[\mathrm{~h}^{-1}\right]\right.$ $=$ influx $[\mathrm{mmol} /$ liter cells $/ \mathrm{h}] / \mathrm{Na}_{0}^{+}$or $\mathrm{L}$-glucose $\left.[\mathrm{mM}]\right)$ as a function of the time after addition of complement it was possible to estimate the time course of the complement-induced change in membrane permeability of EA (Figs. $3 b$ and $4 b$ ). Upon addition of serum, there was a transient increase in the membrane permeability to $\mathrm{Na}^{+}$which peaked at 5 min after addition, and then progressively returned toward the values observed in cells not exposed to serum (Fig. $3 \mathrm{~b}$ ). The change in permeability to L-glucose that followed the addition of serum parallelled that observed in the permeability toward $\mathrm{Na}^{+}$(Fig. 4 b).

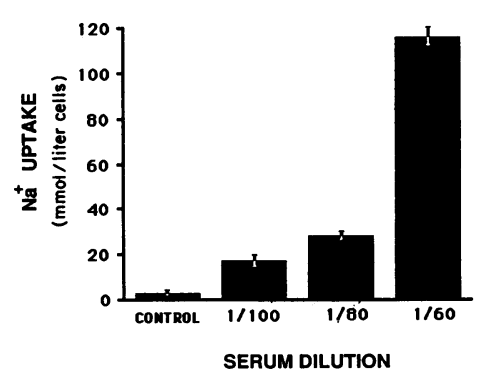

Figure $2 . \mathrm{Na}^{+}$uptake by EA as a function of serum concentration. EA ( 2 $\times 10^{8} / \mathrm{ml}$ ) were exposed to the specified dilution of serum for $60 \mathrm{~min} .{ }^{22} \mathrm{Na}$ was present in the medium at 0 time. Uptake was determined as described in Fig. 1. The lysis at each serum dilution after 60 min was: $11 \%$ at $1 / 100,36 \%$ at $1 / 80$, and $60 \%$ at $1 / 60$.
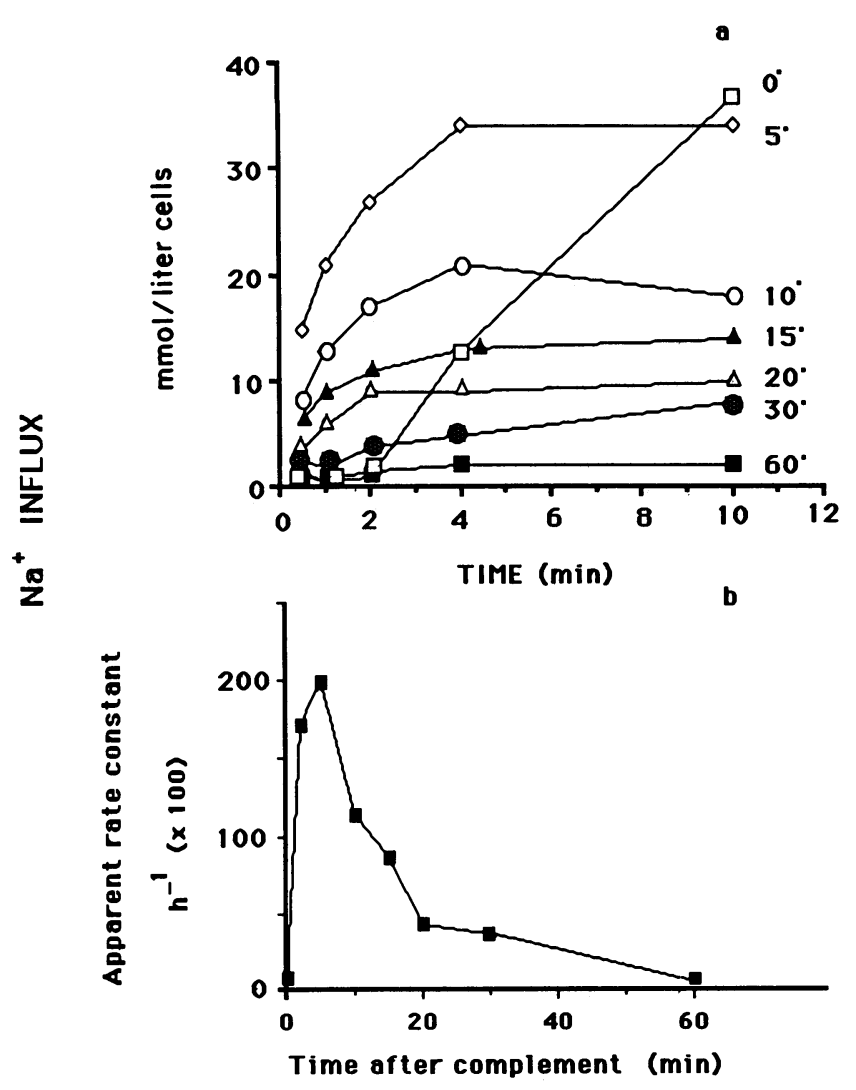

Figure 3. $\mathrm{Na}^{+}$uptake by EA measured at different times after the addition of serum. A suspension containing $2 \times 10^{8}$ cells per $\mathrm{ml}$ was incubated at $37^{\circ} \mathrm{C}$ with a $1 / 120$ dilution of serum, which was added at 0 time. At $0,5,10,15,20,30$, and $60 \mathrm{~min}, 2.2-\mathrm{ml}$ samples were removed and added to tubes containing $\approx 2 \mu \mathrm{Ci}$ of ${ }^{22} \mathrm{Na}$ to form the influx reaction mixture, which was subsequently incubated at $37^{\circ} \mathrm{C}$. From each one of these influx reaction mixtures aliquots of $0.4 \mathrm{ml}$ were removed at $0.5,1,2,4$, and $10 \mathrm{~min}$, diluted into $0.5 \mathrm{ml}$ of isotonic choline chloride solution, which was layered on top of $0.3 \mathrm{ml}$ of phthalate, and then processed as described in Methods. The basal $\mathrm{Na}^{+}$uptake was determined in the absence of serum (data not graphed). The initial rate of the $\mathrm{Na}^{+}$influx into sensitized erythrocytes, was determined from the slope of the lines connecting the 0 time with the 0.5 -min points, except in the case of the 0 time curve where the influx was calculated between the 2- and 4-min points. The apparent rate constant of the influx $\left(\mathrm{h}^{-1}\right)$ was calculated by dividing the influx (in mmol/liter cells/h) by the concentration of $\mathrm{Na}^{+}$ in the medium $(140 \mathrm{mM})$.

To determine how the transient increase in permeability induced by complement activation in unlysed erythrocytes influences the cation content and volume of the cells, the intracellular $\mathrm{Na}^{+}$and $\mathrm{K}^{+}$, as well as cell density distribution, were measured by atomic absorption spectrometry at different intervals after addition of serum. EA contained 15 and 95 $\mathrm{mmol} /$ liter cell of $\mathrm{Na}^{+}$and $\mathrm{K}^{+}$, respectively, a value similar to that of fresh sheep erythrocytes. 6 min after addition of serum (the time of maximal permeability, cf. Figs. 3 and 4) the intracellular $\mathrm{Na}^{+}$had increased 2-3-fold and the intracellular $\mathrm{K}^{+}$ decreased so that the total cation content did not change significantly (Fig. 5). These changes in the internal cation composition of the EA persisted for at least $40 \mathrm{~min}$. To assess the ability of the unlysed EA to recover their original cation composition, a similar experiment was performed but the unlysed cells were 


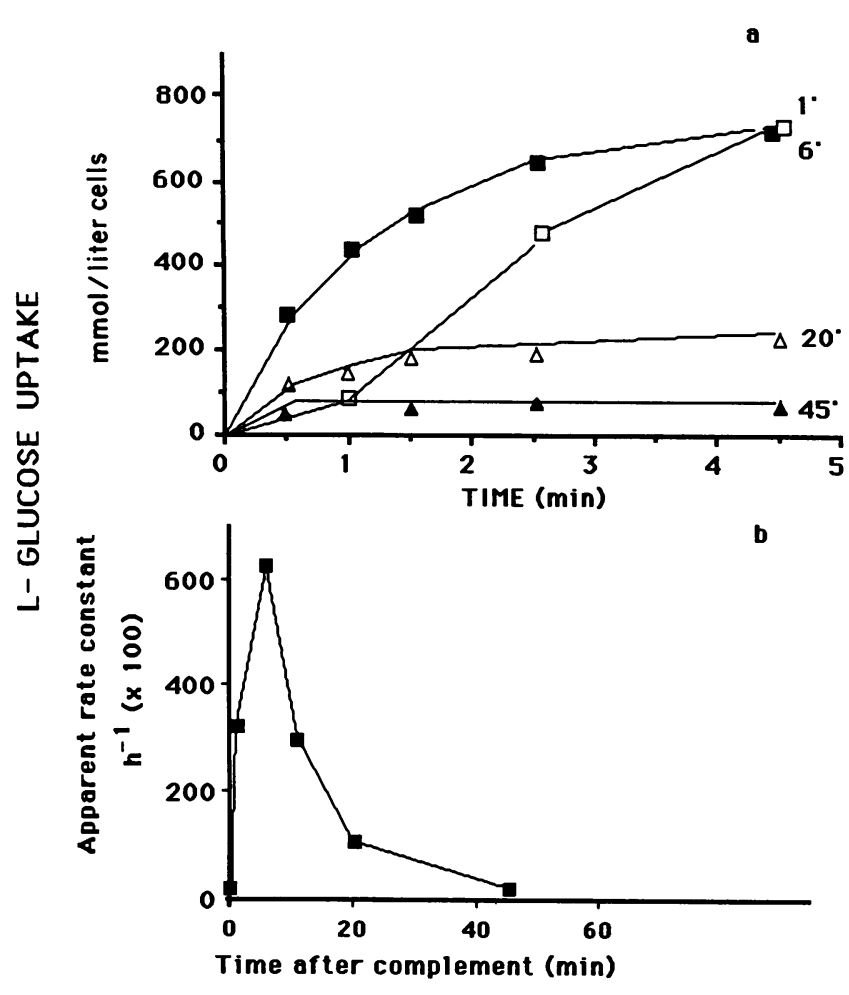

Figure 4. L-glucose uptake by EA measured at different times after the addition of serum. The uptake of L-glucose by EA was measured exactly as described in Fig. 3, except that the influx reaction mixture contained $5 \mathrm{mM} \mathrm{L}$-glucose and $3 \mu \mathrm{Ci}$ of $\mathrm{L}-\left[{ }^{14} \mathrm{C}\right]$ glucose. The initial rate of the L-glucose influx into EA was determined from the slope of the lines connecting the 0 time with the 0.5 minute points. The apparent rate constant of the influx $\left(\mathrm{h}^{-1}\right)$ was calculated by dividing the influx (in $\mathrm{mmol} / \mathrm{liter}$ cells/ $\mathrm{h}$ ) by the concentration of $\mathrm{L}$-glucose in the medium.

kept for $12 \mathrm{~h}$ at $37^{\circ} \mathrm{C}$ in the incubation medium (GVB $\cdot \mathrm{D}^{2+}$ ) supplemented with $4 \mathrm{mM} \mathrm{KCl}$. After this interval the EA contained $15 \mathrm{mmol} /$ liter cell $\mathrm{Na}^{+}$and $95 \mathrm{mmol} /$ liter cell $\mathrm{K}^{+}$, a value similar to that of fresh sheep erythrocytes. Thus, although the unlysed cells experienced a transient change in membrane permeability, their ability to recover and maintain cation gradients across cell membranes implies that they remained viable.

Because of the presence of hemoglobin and other nonpenetrating ions inside erythrocytes, an increase of the membrane permeability of the EA would attract ions and water inward resulting in colloid-osmotic swelling and, eventually, lysis. Accordingly, if the transient increase in the permeability of EA exposed to serum was high enough to permit the cells to approach Donnan equilibrium, the volume of the unlysed cells should be increased. Therefore it would be predicted that the unlysed cells which experienced a transient increase of their membrane permeability during exposure to serum, would have an increase in cell volume. We estimated the cell volume of EA before and after exposure to diluted serum using the phthalate density profile as described in Methods. Cell swelling would produce a shift of the density distribution profile toward lower densities, as observed when erythrocytes are incubated in hypotonic media (25). Surprisingly, the density distribution profiles of the EA did not change after exposure to diluted serum (the mid-point of the density distribution of EA was

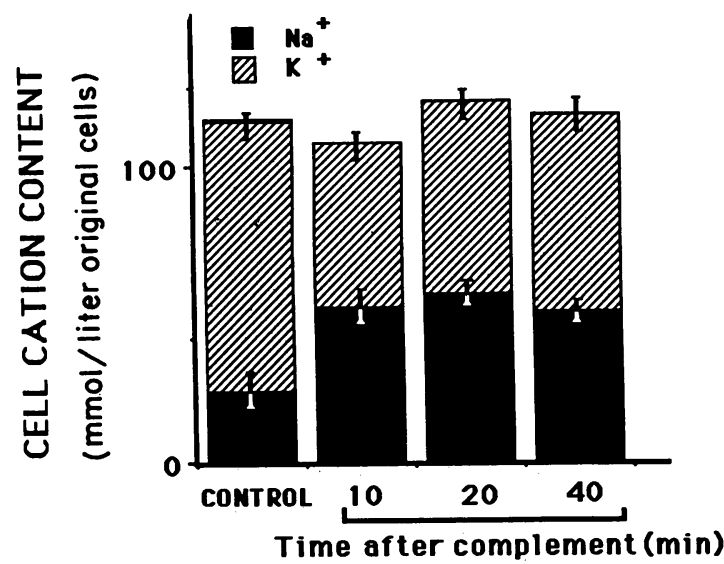

Figure 5. Changes in the intracellular cation composition of EA induced by exposure to sublytic concentrations of complement. Intracellular $\mathrm{Na}^{+}$and $\mathrm{K}^{+}$content of EA from the experiments depicted in Figs. 3 and 4 were determined by atomic absorption spectrometry, as described in Methods.

1.082 and did not change 10,20 , and 40 min after incubation at $37^{\circ} \mathrm{C}$ with $1 / 120$ dilution of serum) indicating that, at the time of the density determination, the volume of the EA exposed to serum was not significantly different from that of the EA not exposed to serum. This observation, together with the observations shown in Fig. 5, suggests that unlysed erythrocytes can either prevent or reverse the colloid-osmotic swelling that must result from the transient increase of their membrane permeability. Since the first density profile of the unlysed cells was performed $10 \mathrm{~min}$ after addition of serum, earlier volume changes would not have been detected by our methods.

In order to evaluate if the complete membrane attack complex were necessary for the transient increase in membrane permeability observed in the unlysed cells, EA were exposed to sera deficient in either $\mathrm{C} 8$ or $\mathrm{C} 9$, in the presence and absence of purified $\mathrm{C} 8$ or $\mathrm{C} 9$, respectively. In the presence of C8 deficient serum, lysis did not occur and no increase in $\mathrm{Na}^{+}$ uptake was detected (Fig. 6). The addition of purified $\mathrm{C} 8 \mathrm{not}$ only reconstituted the deficient serum for lysis, but also produced the transitory change in the membrane permeability of the unlysed cells. To determine if C9 were also required, C9deficient plasma was used as the complement source. In the presence of C9-deficient plasma, a low level of lysis was observed ( $<5 \%$ after $60 \mathrm{~min}$ at the highest plasma concentration tested, Fig. 7). However, this C9-deficient plasma induced a significant increase in the uptake of $\mathrm{Na}^{+}$by the unlysed cells, which reached almost the same value in the presence and absence of purified C9 (inset, Fig. 7). Similar results were obtained when the uptake of L-glucose was studied (data not shown). These results indicate that $\mathrm{C} 9$ was not required to produce the transient increase in the membrane permeability of the erythrocytes induced by complement activation.

\section{Discussion}

The major known nonlytic effect of complement activation on the erythrocyte membrane is the deposition of membrane bound $\mathrm{C} 4 \mathrm{~b}$ and $\mathrm{C} 3 \mathrm{~b}(10,11)$. This study was undertaken to analyze further the effects of nonlytic complement activation 


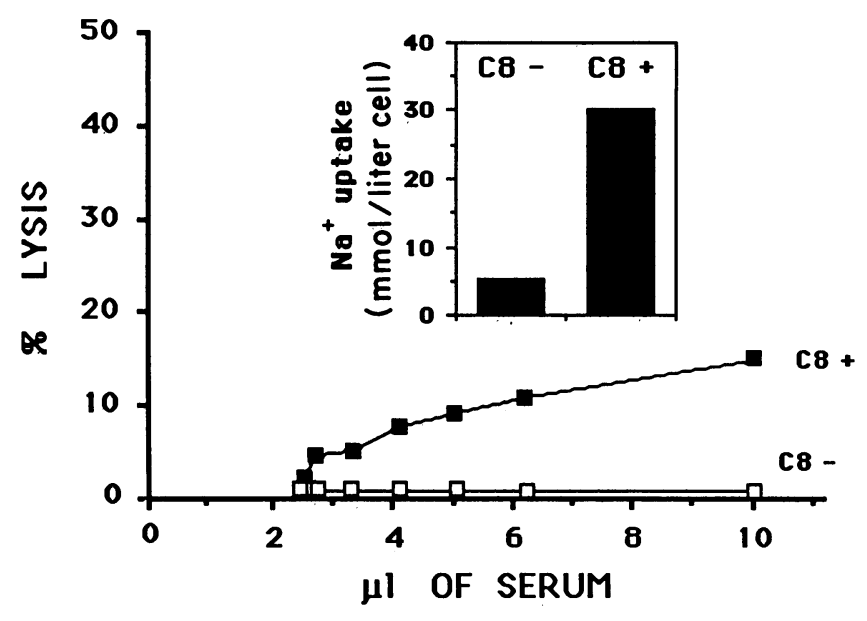

Figure 6. Lysis and $\mathrm{Na}^{+}$uptake by EA exposed to $\mathrm{C} 8$-deficient serum with and without the addition of isolated C8. $20 \mu \mathrm{l}$ of either C8 (20 $\mathrm{U})$ or GBV. $\mathrm{D}^{2+}$ were added to $30 \mu \mathrm{l}$ of C8-deficient serum. EA 2 $\times 10^{8} / \mathrm{ml}$ were exposed to different concentrations of reconstituted $(\square)$ and nonreconstituted ( $\square$ ) C8-deficient serum, and percent lysis determined after $60 \mathrm{~min}$ incubation at $37^{\circ} \mathrm{C}$. (Inset) The uptake of $\mathrm{Na}^{+}$over a period of $1 \mathrm{~h}$ was determined as described in Methods. Reconstituted (C8+) and unreconstituted (C8-) C8-deficient serum (1/75 dilution of each) were added at 0 time simultaneously with the isotope $\left({ }^{22} \mathrm{Na}\right)$.

on erythrocytes. Conditions of complement activation were adjusted to give $\sim 30 \%$ lysis, and thereby achieve a balance between exposure to complement and a useful recovery of unlysed erythrocytes (inset, Fig. 1). Addition of serum caused a rapid uptake of $\mathrm{Na}^{+}$and L-glucose into EA, compared with EA that were not exposed to serum (Fig. $1 a$ and $b$ ). In this experiment a fraction of the isotope uptake during the first 15 min might have been contributed by cells that would have subse-

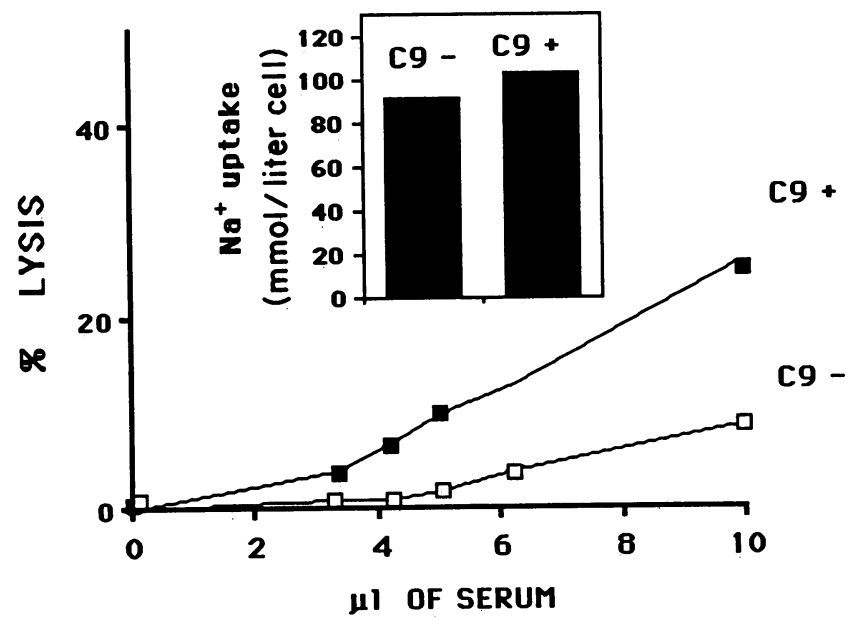

Figure 7. Lysis and $\mathrm{Na}^{+}$uptake by EA exposed to C9-deficient plasma with and without the addition of isolated C9. $7 \mathrm{ng}$ of isolated C9 (Cytotech) were added to $500 \mu \mathrm{l}$ of C9-deficient plasma. Sensitized erythrocytes $2 \times 10^{8} / \mathrm{ml}$ were exposed to different concentrations of reconstituted ( $\square$ ) and nonreconstituted ( $($ ) C9-deficient plasma, and percent lysis determined after $60 \mathrm{~min}$ incubation at $37^{\circ} \mathrm{C}$. (Inset) The uptake of $\mathrm{Na}^{+}$over a period of $1 \mathrm{~h}$ was determined as described in Methods. Reconstituted $(\mathrm{C} 9+)$ and unreconstituted (C9-) C9-deficient plasma (1/50 dilution of each) were added at 0 time simultaneously with the isotope $\left({ }^{22} \mathrm{Na}\right)$. quently lysed. However, the persistence of increased intracellular amounts of both isotopes, ${ }^{22} \mathrm{Na}$ and $\mathrm{L}-\left[{ }^{14} \mathrm{C}\right] \mathrm{glucose}$, after $15 \mathrm{~min}$, a time when there was no further lysis (inset, Fig. 1), indicates that an increased uptake also took place in the unlysed cells. Although an increased influx of $\mathrm{Na}^{+}$stimulated by complement activation, might involve activation of specific transport systems in the cell membrane such as $\mathrm{Na}-\mathrm{Na}$ exchange through the $\mathrm{Na}-\mathrm{K}$ pump, $\mathrm{Na}-\mathrm{H}$ exchange, $\mathrm{Na}-\mathrm{COH}_{3}$ cotransport (reviewed, 26), the increased influx of L-glucose can only be explained by an increase in membrane permeability because there is no transport mechanism for the L-isomers of glucose (27). Moreover, EA exposed to serum lost $\mathrm{K}^{+}$in an amount equal to $\mathrm{Na}^{+}$gain. We conclude that EA which survived exposure to complement developed membrane permeability pathway(s) through which $\mathrm{Na}^{+}, \mathrm{K}^{+}$, and L-glucose can move.

Both the uptake of $\mathrm{Na}^{+}$and L-glucose reached a maximal and constant value when the cells were not at isotopic equilibrium with the extracellular medium (Fig. 1). If the cell population were uniformly affected by activated complement, the absence of isotopic equilibrium when the uptake reached a maximal value would indicate that the enhancement of the membrane permeability which occurred in the unlysed EA was terminated before equilibration. Alternatively, the failure of the isotopes to reach an equilibrium distribution might be explained if only some cells were affected by complement. However, whether the measured changes in $\mathrm{Na}^{+}$and L-glucose uptake were due to changes in the membrane permeability of the total cell population or of a subpopulation of erythrocytes, the changes must have been transient since a prolonged state of increased permeability would have resulted in the eventual lysis of the affected cells, which was not seen (inset, Fig. 1). Confirmation of the transient nature of the increased permeability produced by complement in the unlysed EA was obtained from the flux experiments (Figs. 3 and 4). It is of interest to note that the highest permeability occurred simultaneously with the maximal rate of lysis, an event that has been shown to depend on the insertion of C5b-9 complex(es) in the cell membrane. It has been established previously that these complexes form stable opened channels across the cell membrane that cause an irreversible increase in membrane permeability, leading to colloid-osmotic lysis $(28,29)$. In contrast, the experiments reported here indicate that complement can also induce a reversible change in membrane permeability without compromising the survival of the cells.

The enhanced permeability induced by sublytic complement activation depended on the concentration of complement and correlated with the amount of complement-induced lysis (Fig. 2). Lysis by complement also depends on the concentration of complement, which determines both the number of lesions per cell (30) and the size of each individual lesion (29). The size and/or the number of the sublytic complement lesions may be similarly affected by the concentration of complement.

The complement components necessary to generate the sublytic lesion were assessed using genetically deficient sera. It was reasoned that the terminal complement components might be involved, since membrane permeability changes had been induced. Exposure of EA to $\mathrm{C} 8$ deficient sera did not produce either lysis or increased uptake, indicating that neither complement fragments derived during early complement activation nor C5b-7 could, by themselves, increase the perme- 
ability of the membrane. On the other hand, exposure of sensitized erythrocytes to $\mathrm{C} 9$ deficient plasma produced only minimal lysis, but did increase the membrane permeability of the cells as expressed by the increased uptake of both ${ }^{22} \mathrm{Na}$ (Fig. 7) and L- $\left[{ }^{14} \mathrm{C}\right]$ glucose (not shown). The addition of purified $\mathrm{C} 9$ to the C9-deficient plasma only slightly increased the uptake of either isotope, although it did generate a threefold increase in the amount of lysis (Fig. 7). These data are consistent with a model in which transiently opened C5b-8 channels are responsible for the complement-induced, self-limited, increase in membrane permeability observed in our experiments. It is of interest to note that the conductance generated in lipid bilayers by $\mathrm{C} 5 \mathrm{~b}-8$, but not that generated by $\mathrm{C} 5 \mathrm{~b}-9$, is dependent on the voltage applied to the electrical field across the membrane (31). Voltage gating might be involved in the operation of the C 5 b- 8 lesions produced in the erythrocyte membrane by sublytic concentrations of complement.

C5b-8 can lyse erythrocytes, albeit at a much slower rate than that produced by C5b-9 (32-36). However, the transient increase in permeability produced by sublytic complement concentrations, which we propose might be mediated by C5b-8, did not lead to lysis. The reason why C5b-8 under some circumstances may produce lesions that lead to slow lysis while under other circumstances, such as those described in this work, produces only transient changes in membrane permeability, is not known at present. Nor is it known whether C9, when present in the medium, binds to the C $5 \mathrm{~b}-8$ lesion which induces the transient change in membrane permeability.

It is interesting that those erythrocytes which survived complement activation did not swell although they underwent a transient but large increase of their membrane permeability. The complement-induced increase in permeability of the membrane allowed equimolar movements of $\mathrm{Na}^{+}$and $\mathrm{K}^{+}$(Fig. $5)$, and no increase in cell volume. A similar phenomenon has been observed in the unlysed cells exposed to mellitin (37), a channel forming protein. This could reflect an equivalent exchange of external $\mathrm{Na}^{+}$for internal $\mathrm{K}^{+}$through the complement-induced channels. This would not influence the total ion distribution between intra- and extracellular compartments nor would it influence water movement. However, such an exclusive exchange of cations is unlikely since the transient permeability pathway induced by complement is large enough to permit the passage of L-glucose (Fig. 4). Alternatively, it is possible that cell mechanisms that prevent swelling were activated secondary to the sudden increase in permeability induced by complement, or that the cells could have swollen and recovered before the first density distribution was determined.

It is well documented that nucleated cells are more resistant to complement mediated lysis than erythrocytes (2), and the basis for this resistance depends in part on the ability of the nucleated cell to eliminate the terminal complement attack complex from its plasma membrane (3-7). Our data indicates that erythrocytes might also recover from sublytic complement damage. Platelets, other nonnucleated cells, have been documented to recover from the permeability changes produced by sublytic complement (38). Whether the termination of enhanced permeability in the erythrocytes depends on intrinsic properties of the terminal attack complex, or whether it depends on an active erythrocyte process is not known at present. The final recovery of the cell's normal cation content, however, must depend on active erythrocyte metabolism, because cation gradients are restored.
The transient fluxes of ions and/or other molecules due to the insertion of terminal complement complexes in the membrane of erythrocytes or other cell types may be biologically important. Calcium influx through transient permeability pathways induced by complement may trigger a variety of $\mathrm{Ca}^{2+}$-calmodulin dependent cell responses. In some nucleated cells and platelets sublytic complement activation stimulates the production and release of cell mediators probably secondary to a rise in intracellular calcium (reviewed, 39). Furthermore, calcium influx through complement $\mathrm{C} 5 \mathrm{~b}-8$ complexes leads to formation and release of prostacyclin by endothelial cells (40). Thus, it is possible that transient changes in membrane permeability due to sublytic activation of complement may contribute to regulate physiological and/or pathological functions of the cells.

\section{Acknowledgments}

The authors are grateful to Dr. Magdalena T. Tosteson for helpful discussions of the data and comments on the manuscript. We thank Alane Taratuska for her excellent technical assistance.

Work supported by National Institutes of Health grants NS-23367, HL-33768, HL-36076. Dr. Nicholson-Weller is a Scholar of the Leukemia Society of America.

\section{References}

1. Green, H., P. Barrow, and B. Goldberg. 1959. Effect of antibody and complement on permeability control in ascites tumor cells and erythrocytes. J. Exp. Med. 110:699-713.

2. Koski, C. L., L. E. Ramm, C. H. Hammer, M. M. Mayer, and M. L. Shin. 1983. Cytolysis of nucleated cells by complement: cell death displays multi-hit characteristics. Proc. Natl. Acad. Sci. USA. 80:3816-3820.

3. Ohanian, S. H., and S. I. Schlager. 1981. Humoral immune killing of nucleated cells: mechanisms of complement-mediated attack and target cell defense. CRC Crit. Rev. Immunol. 1:165-209.

4. Ramm, L. E., M. B. Whitlow, C. L. Koski, M. L. Shin, and M. M. Mayer. 1983. Elimination of complement channels from the plasma membrane of U937, a nucleated mammalian cell line: temperature dependence of the elimination rate. J. Immunol. 131:1411-1415.

5. Carney, D. F., C. L. Koski, and M. L. Shin. 1985. Elimination of terminal complement intermediates from the plasma membrane of nucleated cells: the rate of disappearance differs for cells carrying C5b-7, C5b-8 or a mixture of C5b-8 with a limited number of C5b-9.J. Immunol. 134:1804-1809.

6. Campbell, A. K., and B. P. Morgan. 1985. Monoclonal antibodies demonstrate protection of polymorphonuclear leukocytes against complement attack. Nature (Lond.). 317:164-166.

7. Morgan, B. P., J. R. Dankert, and A. F. Esser. 1986. Recovery of human neutrophils from complement attack: removal of the membrane attack complex by endocytosis and exocytosis. 1987. J. Immunol. 138:246-253.

8. Mayer, M. M., C. H. Hammer, D. W. Michaels, and M. L. Shin. 1979. Immunologically mediated membrane damage: the mechanism of complement action and the similarity of lymphocyte-mediated cytotoxicity. Immunochemistry. 15:813-831.

9. Muller-Eberhard, H. J. 1985. Transmembrane channel-formation by five complement proteins. Biochem. Soc. Symp. 50:235-246.

10. Salama, A., S. Bhakdi, C. Mueller-Eckhardt, and W. Kayser. 1983. Deposition of the terminal C5b-9 complement complex on erythrocytes by human red cell autoantibodies. Br. J. Haematol. 55:161-169.

11. Szymanski, I. O., R. E. Swanton, and P. R. Odgren. 1984. Quantitation of the third component of complement on stored red cells. Transfusion. 24:194-197. 
12. Nicholson-Weller, A., J. Burge, D. T. Fearon, P. F. Weller, and K. F. Austen. 1982. Isolation of a human erythrocyte membrane glycoprotein with decay accelerating activity for C3 convertases of the complement system. J. Immunol. 129:184-189.

13. Schonermark, S., E. W. Rauterberg, M. L. Shin, S. Loke, D. Roelcke, and G. M. Hänsch. 1986. Homologous species restriction in lysis of human erythrocytes: a membrane derived protein with C8binding capacity functions as an inhibitor. J. Immunol. 136:17721776.

14. Zalman, L. S., L. M. Wood, and H. J. Müller-Eberhard. 1986. Isolation of human erythrocyte membrane protein capable of inhibiting expression of homologous complement transmembrane channels. Proc. Natl. Acad. Sci. USA. 83:6975-1679.

15. Pangburn, M. K., R. D. Schreiber, and H. J. Müller-Eberhard. 1983. Deficiency of an erythrocyte membrane protein with complement regulatory activity in paroxysmal nocturnal hemoglobinuria. Proc. Natl. Acad. Sci. USA. 80:5430-5434.

16. Medof, M. E., T. Kinoshita, and V. Nussenzweig. 1984. Inhibition of complement activation on the surface of cells after incorporation of decay-accelerating factor (DAF) into their membranes. J. Exp. Med. 160:1558-1578.

17. Thompson, R. A., and P. J. Lachmann. 1970. Reactive lysis: the complement-mediated lysis of unsensitized cells. I. The characterization of the indicator factor and its identification as C7. J. Exp. Med. 131:629-641.

18. Lachmann, P. J., and R. A. Thompson. 1970. Reactive lysis: the complement-mediated lysis of unsensitized cells. II. The characterization of activated reactor as $\mathrm{C} 56$ and the participation of $\mathrm{C} 8$ and $\mathrm{C} 9$. J. Exp. Med. 131:643-657.

19. Tosteson, D. C., and J. F. Hoffman. 1960. The regulation of cell volume by active cation transport in high and low potassium sheep red cells. J. Gen. Physiol. 44:169-193.

20. Densen, P., E. Brown, G. O'Neill, F. Tedesco, R. A. Clark, M. Frank, D. Webb, and J. Myers. 1983. Inherited deficiency of C8 in a patient with recurrent meningococcal infections. Further evidence for a dysfunctional C8 molecule and nonlinkage to the HLA system. $J$. Clin. Immunol. 3:90-99.

21. Tedesco, F., P. Densen, M. A. Villa, B. H. Petersen, and G. Sirchia. 1983. Two types of dysfunctional eighth component of complement (C8) molecules in $\mathrm{C} 8$ deficiency in man. J. Clin. Invest. 71:183-191.

22. Lint, T. F., H. J. Zeitz, and H. Gewurz. 1980. Inherited deficiency of the ninth component of complement in man. J. Immunol. 125:2252-2257.

23. Ferreira, H. G., and V. L. Lew. 1976. Use of ionophore A21387 to measure cytoplasmic $\mathrm{Ca}++$ buffering and activation of the $\mathrm{Ca}$ pump by internal Ca. Nature (Lond.). 259:47-49.

24. Danon, D., and Y. Marikozsky. 1964. Determination of den- sity distribution of red cell populations. J. Lab. Clin. Med. 64:668674.

25. Brugnara, C., and D. C. Tosteson. 1987. Cell volume, K transport, and cell density in human erythrocytes. Am. J. Physiol. 252:C269-C276.

26. Sachs, J. R., P. Knauf, and P. B. Dunham. 1974. Transport through the red cell membrane. In The Red Blood Cell. D. M. Surgenor, editor. Academic Press, New York. 613-703.

27. Berwick, G. J. 1974. General red cell metabolism. In The Red Cell. D. M. Surgenor, editor. Academic Press, New York. 387-508.

28. Bhakdi, S., and J. Tranum-Jensen. 1978. Molecular nature of the complement lesion. Proc. Natl. Acad. Sci. USA. 75:5655-5659.

29. Ramm, L. E., and M. M. Mayer. 1980. Life-span and size of the transmembrane channel formed by large doses of complement. J. Immunol. 124:2281-2287.

30. Boyle, M. D. P., and T. Borsos. 1979. Studies on the terminal stages of immune hemolysis. V. Evidence that not all complementproduced transmembrane channels are equal. J. Immunol. 123:71-76.

31. Michaels, D. W., A. S. Abramovitz, C. H. Hammer, and M. M. Mayer. 1976. Increased ion permeability of planar lipid bilayer membranes after treatment with the C5b-9 cytolytic attack mechanism of complement. Proc. Natl. Acad. Sci. USA. 73:2852-2856.

32. Stolfi, R. L. 1968. Immune lytic transformation: A state of irreversible damage generated as a result of the reaction of the eighth component in the guinea pig complement system. J. Immunol. 160:46-54.

33. Tamura, N., A. Shimada, and S. Chang. 1972. Further evidence for immune cytolysis by antibody and the first eight components of complement in the absence of C9. Immunology. 22:131-137.

34. Gee, A. P., M. D. P. Boyle, and T. Borsos. 1980. Distinction between C8-mediated and C8/C9-mediated hemolysis on the basis of independent ${ }^{86} \mathrm{Rb}$ and hemoglobin release. J. Immunol. 124:19051910.

35. Kitamura, H., and K. Nagaki. 1981. Inhibitory effect of sugars on the spontaneous lysis of EAC1-8. Mol. Immunol. 18:985-990.

36. Ramm, L. E., M. B. Whitlow, and M. M. Mayer. 1982. Size of the transmembrane channels produced by complement proteins C5b-8. J. Immunol. 129:1143-1146.

37. Tosteson, M. T., S. J. Holmes, M. Razin, and D. C. Tosteson. 1985. Melittin lysis of red cells. J. Membr. Biol. 87:35-44.

38. Sims, P. J., and T. Wiedmer. 1986. Repolarization of the membrane potential of blood platelets after complement damage: evidence for a $\mathrm{Ca}^{++}$-dependent exocytotic elimination of $\mathrm{C5b}-9$ pores. Blood. 68:556-561.

39. Morgan, B. P., J. P. Luzio, and A. K. Campbell. 1986. Intracellular $\mathrm{Ca}^{++}$and cell injury: a paradoxical role for $\mathrm{Ca}^{++}$in complement membrane attack. Cell Calcium. 7:399-411.

40. Suttorp, N., W. Seeger, S. Zinsky, and S. Bhakdi. 1987. Complement complex C5b-8 induces $\mathrm{PGI}_{2}$ formation in cultured endothelial cells. Am. J. Physiol. 253:C13-C21. 